\title{
Night of the Living Jews (Noc żywych Żydów)
}

Autor: Igor Ostachowicz

First Published: 2012

Theatre Adaptation: Teatr Dramatyczny, Warsaw (2014).

Translations: French (La nuit des Juifs-vivants, 2016); Slovenian (Noč živih Židov, 2019).

About the Author: Igor Ostachowicz (1968) is a writer and former specialist in international relations. During 2007-2014 he was undersecretary and secretary of state in the Chancellery of the Prime Minister.

Further Important Publications: Zielona wyspa (2015, The Green Island; novel).

\section{Content and Interpretation}

Igor Ostachowicz's novel has caused fierce discussion among scholars of Holocaust literature, just as it has polarised and divided the broader public. This is due in large part to the author's strategy in presenting the subject, considered by many to be controversial, offensive, and inappropriate. Night of the Living Jews presents the fictional story of a Warsaw resident who becomes entangled in the history of the Holocaust as he is visited by living corpses of Jews exterminated during the war. By the conceit of the novel, they have remained all these years under the rubble and in the cellars of modern-day Warsaw, the inhabitants of an underground city. The story culminates with a scene set in Warsaw's biggest shopping mall, Arcadia, where the main characters must fight for their lives. In this way, Ostachowicz's strategy for representing history takes its cues from popular culture, most explicitly from the horror film Night of the Living Dead (1968), but there are also allusions to Tarantino's Inglorious Bastards (2009) (Sobolewska, 2012).

The motif of living corpses is thus linked to the notion of Jews who want not so much to avenge themselves (as in Tarantino's film) as to change their future fate. The ludic aspect of the plot is reinforced by comic portrayals of Jews who cannot find their way in the everyday reality of a world dominated by commercial culture. Gradually, however, they give in to its charms (they go shopping, for instance). The writer does not shy away from the use of slapstick: in one scene, for example, a Jewish boy on a shopping spree loses his hand. The controversy generated by the novel is due primarily to its rejection of the prevailing form of Holocaust memorialisation, which is to say, the serious approach that people are accustomed to. It is this aspect of Ostachowicz's novel, on its surface, that has elicited reactions of disgust and even outrage. On the other hand, by provoking readers in this way, the novel focuses our attention pre-

D Open Access. () 2021 Beata Przymuszata, published by De Gruyter. (cc) BY-NC-ND This work is licensed under a Creative Commons Attribution-NonCommercial-NoDerivatives 4.0 License. https://doi.org/10.1515/9783110671056-072 
cisely on these negative reactions (as anticipated by the writer), and on those who fail to go further than a superficial reading. Seen from a different perspective - combining these facts in a different way -, we find a very different story: the Jews who inhabit the underground city are those who have not been mourned, who were never mentioned, and who are not missed.

It is this hidden challenge within the novel that most defies the living, forcing us to change our reading habits. Similarly, the grotesque nature of the contemporary world as depicted in the novel, in relation to the deceased Jews, does violence to our sense of reality, and undermines all references to the real-world situation. Considering that the Warsaw district of Muranów was erected on the ruins of the ghetto and on other neighbourhoods destroyed by the Germans at the close of the war, the absence of Jews takes on new meaning. Namely, it calls attention to a certain perspective from which it made better financial sense to build on the rubble of the ghetto than to excavate the bodies - the dead really were left behind beneath the foundations of the new buildings (Chomątowska, 2012, p. 169). From this perspective, Jews may be absent from the streets of Warsaw, but their living corpses have brought them back into plain view. The plot of Night of the Living Jews unfolds according to its provocative premises: the arrival of Jews is met with hostility, in particular from a group with Fascist roots that does not want Jews in Poland. The protagonist takes up a fight with this belief and its adherents:

\footnotetext{
The moment has come, there's no way to hide from it, you have to face the truth. Tell my aunts, uncles, neighbours, my whole Polish family, who have been sitting comfortably on the couch in front of the TV: Yes, it's true, corpses are walking around the city, and I wonder what the sanitary service will say about it, and it's possible that they'll be looking for their cutlery and paperwork, not to mention their real estate, and I don't even know if they like you. But they have shown some degree of tolerance, and because the situation makes me nauseous, and in light of this truth, which you already know, I intend to fight for the fallen, for their right to come and go as they please, to do what they wish. You don't like it? I'll smack you with my pipe (Ostachowicz, 2012, p. 235).
}

However, it is difficult to consider the protagonist's fight as a straightforwardly idealistic gesture. He too is caught up in an attitude of self-defence, he too is concerned for the protection of his image and privileges. The question then is: will he be capable, in spite of all, of giving aid to others? Does the gesture only count when it is based on idealistic motivations? These are the questions the reader is left with at the end of the novel. The writer directs the emotions of his readers in the manner of a critical artist, arousing feelings of discomfort, or refusing to resolve them, confronting his audience with the meaning of their own reactions. Horror is not just a popculture convention. In the right hands, it tells the terrifying story of a story that forgets the dead. Horror is the absence of memory (Przymuszała, 2016). 


\section{Main Topics and Problems:}

Night of the Living Jews is an excellent example of the way a certain dispute plays out between the perception of popular culture and the presentation of topics of exceptional importance to history. The provocation at the heart of Ostachowicz's gesture was so strong that many readers felt he had gone too far, and while the success of the novel was all but guaranteed by this carefully calculated scandal, it seemed to come at the expense of more substantive reflections on the author's purpose. Over time, however, interpretations have gone much further, and researchers have increasingly pointed to the purposeful semantic play of Ostachowicz's approach. Reception has turned now from the preliminary aesthetic problem posed by the novel to the PolishJewish relations, historical and contemporary, that underlie it. Justyna Kowalska-Leder, for example, sees the Night of the Living Jews as a kind of projection of Polish fears and phobias connected with the Shoah, suggesting that the generic conventions of horror are a veiled reference to the return of repressed guilt, just as the murdered return in their dreams.

At the same time, the figure of Jewish zombies will remind us of the myth of the Jewish vampire ritual murder, so that the depiction of Jewish corpses becomes highly ambivalent, at once evoking and contradicting stereotypical notions about Jews (Kowalska-Leder, 2014, pp. 779-780). Other research has pointed to the great potential presented by the figure of "animated dead bodies" in their relation to the burial place. Roma Sendyka notices, above all, a gesture in Ostachowicz's work that engages with the unclear status of the Jews who died in the ghetto during and after the uprising, and who were not given a burial but merely absorbed by the rubble. In this sense, the spectral presence of the dead could be seen as an extension of lingering guilt concerning the lack of proper treatment of the corpses, and the protagonist's actions as a kind of redress (Sendyka, 2014, p. 296). Czapliński points out how Ostachowicz's images of Jews marked by corporeal violence function as disgusting literal representations of their suffering. He thus proposes reading Night of the Living Jews as an example of the expansion of an image - circulating in the literature of recent years - of the Shoah as an "abomination" from which we want to distance ourselves and which, by attacking all our senses, does not allow us to reduce the topic to theoretical deliberations. This in turn highlights the necessity of reworking our ideas about ourselves, and about our perception of the community (Czapliński, 2016, p. 392-394). The reception of the Night of the Living Jews as a novel that aims only to scandalise, as we see by these examples, has thus significantly evolved - and will probably continue to evolve.

\section{Cited Works}

Chomątowska, B. (2012). Stacja Muranów. Wołowiec: Wydawnictwo Czarne. Czapliński, P. (2016). Zagłada jako horror. Kilka uwag o literaturze polskiej 1985-2015. Zagłada Żydów. Studia i Materiały, (12), pp. 375-394. Kowalska-Leder, J. (2014). Literatura polska ostatniego dziesięciolecia wobec Zagłady próby odpowiedzi na nowe wyzwania. Zagłada Żydów. Studia i Materiały, (10), pp. 768-802. Ostachowicz, I. 
(2012). Noc żywych Żydów. Warszawa: Wydawnictwo W.A.B. Przymuszała, B. (2016). Smugi Zagłady. Emocjonalne i konwencjonalne aspekty tekstów ofiar i ich dzieci. Poznań: Wydawnictwo UAM. Sobolewska, J. (2014). Mściciel z Muranowa. Available at: http://www.polityka.pl/tygodnikpolityka/kultura/ksiazki/1525917,1,recenzja-ksiazkiigor-ostachowicz-noc-zywych-zydow.read [Accessed: 24.04.2014]. Sendyka, R. (2014). Miejsca, które straszą (afekty i nie-miejsca pamięci). In: Z. Budrewicz, R. Sendyka, R. Nycz, eds., Pamięć i afekty. Warszawa: Wydawnictwo Instytut Badań Literackich PAN, pp. 285-307.

\section{Further References}

Czapliński, P. (2009). Zagłada i profanacje. Teksty Drugie, 20(4), pp. 199-213. Czeczot, K. (2011). Etyka happy endu. Oniryczne i ironiczne przedstawienie Zagłady. In: B. A. Polak, T. Polak, eds., Porzucić etyczna arogancję. Ku reinterpretacji podstawowych pojęć humanistyki w świetle wydarzenia Szoa. Poznań: Wydawnictwo Naukowe Wydziału Nauk Społecznych, pp. 113-130. Link-Lenczowska, M. (2014). More than an Average Zombie Thriller. New Eastern Europe, (2), pp. 192-196. Nowak, D. (2016). Jews Represent in Muranów Neighborhood in Igor Ostachowicz's The Night of the Living Jews. Studia Slavica, (1), pp. 25-32. Tomczok, M. (2017). Czyja dzisiaj jest Zagłada? Retorykaideologia-popkultura. Warszawa: Wydawnictwo Instytut Badań Literackich PAN. Żurek, S. J. (2016). The Shoah in Contemporary Polish Fiction (after 1989). pl.it - rassegna italiana di argomenti polacchi, (7), pp. 187-195. 